\title{
Государственная служба в органах прокуратуры в системе государственной саужбы в правоохранительной сфере
}

\author{
А. В. СМИРнов \\ Прокуратура Вологодской области, г. Вологда, Российская Федерация \\ ORCID: https://orcid.org/0000-0003-0560-0841, e-mail: smirnov5146@yandex.ru
}

Р е фер ат

Введение: настоящая статья посвящена анализу действующего национального законодательства, регулирующего вопросы функционирования института государственной службы. Цель: исследование федеральных законодательных актов, содержащих положения, раскрывающие перечень государственных органов, относящихся к числу правоохранительных, а также причин отказа законодателя от категории «правоохранительная служба». Методологическая основа: общенаучные и специальные методы, в том числе сравнительно-правовой, системный и логический, анализа и синтеза. Результаты: отмечается несогласованность нормативной правовой базы, не позволяющая установить общность и особенности административно-правового статуса таких органов, а также препятствующая дальнейшему развитию теории административного права в исследовании проблем института государственной службы. На основе анализа видов функциональной деятельности государственных органов делается вывод об отнесении службы в органах прокуратуры к категории государственной службы, связанной с правоохранительной деятельностью, отмечается ее сходство и различие со службой в иных государственных органах, осуществляющих правоохранительные функции, в том числе в учреждениях и органах уголовно-исполнительной системы. В русле методологии интегративного правопонимания дается авторское определение данной категории как профессиональной деятельности, осуществляемой от имени государства служащими, занимающими должности в уполномоченных федеральных государственных органах и наделенными в силу закона полномочиями по применению мер государственного принуждения, направленной на охрану законности и правопорядка, защиту прав и свобод человека, общественных и государственных интересов, борьбу с преступлениями и другими правонарушениями либо связанной с выполнением функций внутреннего управления и кадрового обеспечения этих органов. Подчеркивается, что такая служба реализуется в строгом соответствии с правилами, установленными административно-правовыми нормами, и на основе этических принципов и нравственных начал, формирующих ориентацию служащих на достижение общественно полезных целей и интересов самого государства. Научная и практическая значимость статьи заключается в том, что сделанные в ней выводы могут быть использованы в научной, учебной и правотворческой деятельности.

К люче в ы е слова: государственная служба; правоохранительные органы; правоохранительная деятельность; контрольно-надзорная деятельность; правозащитная деятельность; органы прокуратуры; работники прокуратуры.

12.00.14 - Административное право; административный процесс.

Д ля ц и ти ро в ан и я: Смирнов А. В. Государственная служба в органах прокуратуры в системе государственной службы в правоохранительной сфере. Пенитенциарная наука, 2021, т. 15, № 1 (53), c. 96-106. DOI 10.46741/2686-9764-2021-15-1-96-106.

\section{State Service in the Prosecutor's Office in the System of State Service in the Law Enforcement Sphere}

\author{
ANDREI V. SMIRNOV \\ Prosecutor's Office of the Vologda Oblast, Vologda, Russian Federation \\ ORCID: https://orcid.org/0000-0003-0560-0841, e-mail: smirnov5146@yandex.ru
}


A bstract. Introduction: the paper analyzes current Russian legislation regulating the functioning of the institute of state service. Aim: to study federal legislative acts containing provisions that define the list of state bodies that are classified as law enforcement agencies, and to look into the reasons why the legislator abandons the term "law enforcement service". Methods: general scientific and special methods, including comparative legal, comprehensive, logical methods, analysis and synthesis. Results: we reveal certain inconsistencies in the regulatory framework that make it difficult to establish common features and specifics of administrative and legal status of such bodies; these inconsistencies also impede further development of the theory of administrative law when studying the institution of state service. Conclusion: based on the analysis of the types of functional activities of state bodies, we conclude that the service in the prosecutor's office is classified as the state service related to law enforcement activity; we note its similarity and difference in relation to the service in other state bodies that perform law enforcement functions, including institutions and bodies of the penal system. In line with the methodology of integrative legal understanding, we define the service in the prosecutor's office as the professional activity carried out on behalf of the state by employees holding positions in authorized federal state bodies and empowered by law to apply state enforcement measures aimed at protecting law and order, human rights and freedoms, public and state interests, combating crimes and other offenses, or the professional activity related to the performance of the functions of internal administration and staffing of these bodies. We emphasize that such service is implemented in strict accordance with the rules established by administrative and legal norms, and on the basis of ethical principles and moral principles that form the orientation of employees toward achieving socially useful goals and interests of the state itself. Scientific and practical significance of the article lies in the fact that the conclusions made in it can be used in scientific, educational and law-making activities.

Ke y w ords: state service; law enforcement agencies; law enforcement activities; control and supervisory activities; human rights activities; prosecutor's office agencies; prosecutor's office employees.

12.00.14 - Administrative law; administrative process.

F or c it a ti o n: Smirnov A.V. State service in the prosecutor's office in the system of state service in the law enforcement sphere. Penitentiary Science, 2021, vol. 15, no. 1 (53), pp. 96-106. DOI 10.46741/2686-9764-2021-15-1-96-106.

\section{Введение}

Реформирование системы государственного управления не могло не отразиться на состоянии органов прокуратуры, приоритетах в их функционировании, применяемых административно-правовых формах и методах работы. Именно поэтому решение проблем развития прокурорской службы, как и института государственной службы в целом [13], невозможно в отрыве от общих вопросов развития государства и права. Подобные изменения требуют переосмысления целей и задач, стоящих перед органами прокуратуры, а также базовых основ внутриведомственных служебных отношений.

Основы правового положения российских государственных служащих были заложены Федеральным законом от 31.07.1995 № 119Ф3 «Об основах государственной службы Российской Федерации». Пришедший на смену ему Федеральный закон от 27.05.2003 № 58-Ф3 «О системе государственной службы Российской Федерации» (далее - За- кон) ознаменовал начало создания системы управления государственной службой [23] и перехода от структуры категорированных должностей к государственной службе трех самостоятельных видов: государственной гражданской, военной и правоохранительной.

Однако процесс формирования системы государственной службы так и не был завершен. Несмотря на прямое указание в п. 2 ст. 3 Закона на необходимость принятия отдельных федеральных законов о видах государственной службы в целях обеспечения реализации принципов построения и функционирования системы государственной службы, правоохранительная служба спустя продолжительный период времени так и не нашла своего правового закрепления.

Во многом, вероятно, это было обусловлено различиями в позициях самих правоохранительных органов, отличающихся консерватизмом, не желающих, чтобы служебная деятельность их сотрудников основывалась на идентичных с другими органа- 
ми законоположениях и в результате этого потеряла сложившуюся веками индивидуальность.

В качестве официальных мотивов отказа назывались отсутствие в законодательстве определения понятия «правоохранительный орган», критериев и признаков, которым он должен соответствовать; отсутствие четко определенной структуры таких государственных органов; учет зарубежного опыта [16], который формировался путем не столько принятия общих законов, сколько создания актов по каждому виду правоохранительной службы [15].

Также одной из причин мог явиться наметившийся в период действия рассматриваемого Закона плюрализм правовых школ, который привел к возникновению отличных друг от друга позиций их представителей при определении содержания правоохранительной службы, перечня государственных органов, сотрудники которых проходят службу данного вида [20].

Пожалуй, наибольшие споры вызывало отнесение к сфере правоохранительной службы судебных органов и органов прокуратуры. И если полемика по первым из них разрешалась в полной мере результатами анализа норм действующего законодательства (разделение в п. «л» ч. 1 ст. 72 Конституции Российской Федерации одного из предметов совместного ведения Российской Федерации и ее субъектов на кадры судебных и правоохранительных органов; отнесение судей к государственным должностям Российской Федерации, исключающее возможность регулирования их деятельности федеральным законом «О системе государственной службы Российской Федерации»), то явные правовые основания, с достоверностью позволявшие включить службу в органах прокуратуры в блок правоохранительной службы либо исключить ее оттуда, отсутствовали.

Используя возникший правовой вакуум, некоторые авторы говорили о несправедливости причисления прокуратуры к правоохранительным органам, поскольку прокуроры не наделены полномочием возбуждения и расследования уголовных дел, несмотря на уголовное преследование, осуществляемое в суде [17]. Другие приходили к подобным выводам, опираясь на особый статус органов прокуратуры, исключающий отнесение их к какой-либо ветви власти, а также первостепенность регулирования трудовых отношений их работников законодательством о труде [6; 14, с. 8]

Развеять возникшие споры был призван федеральный закон «О правоохранительной службе Российской Федерации», разработка которого длилась почти десятилетие, но проект так и не был реализован.

На состоявшемся 10 октября 2012 г. заседании Комиссии при Президенте Российской Федерации по вопросам реформирования и развития государственной службы впервые на официальном уровне было предложено отказаться от термина «правоохранительная служба» и внести в базовый закон изменения, уточнив, что государственная служба включает в себя помимо государственной гражданской и военной службы также иные виды государственной службы. Отличия в прохождении службы иных видов в конкретном государственном органе предлагалось определить в специальных законах [5].

Точка в данном вопросе была поставлена только с принятием Федерального закона от 13.07.2015 № 262-Ф3 «О внесении изменений в отдельные законодательные акты Российской Федерации в части уточнения видов государственной службы и признании утратившей силу части 19 статьи 323 Федерального закона "О таможенном регулировании в Российской Федерации"», в который и были включены соответствующие положения.

Между тем нельзя сделать однозначный вывод о том, что новая редакция федерального закона «О системе государственной службы Российской Федерации» внесла достаточную ясность в дело определения возможных видов государственной службы. До настоящего времени Закон не содержит какого-либо понятия государственной службы иных видов (в отличие от прежней редакции, содержавшей определение понятия «правоохранительная служба»), что не позволяет с достоверностью определить, в каких государственных органах она осуществляется.

В целом же можно констатировать, что федеральный закон от 13.07.2015 № 262-Ф3 не разделил государственную службу на три вида, как ранее, а создал предпосылки для появления неограниченного количества видов службы, к каждому из которых есть единое требование - установление соответствующим федеральным законом.

Не останавливаясь на определении всей структуры государственной службы иных 
видов, отметим, что положения ст. 40 Федерального закона от 17.01.1992 № 2202-1 «О прокуратуре Российской Федерации» (далее - Закон о прокуратуре), устанавливающие, что служба в органах и организациях прокуратуры является федеральной государственной службой, а прокурорские работники являются федеральными государственными служащими, исполняющими обязанности по должности федеральной государственной службы, правовое положение и условия службы которых определяются настоящим федеральным законом, позволяют без всяких сомнений сделать вывод об отнесении к рассматриваемой категории видов государственной службы и службу в органах прокуратуры Российской Федерации.

Стоит, однако, подчеркнуть, что одной из особенностей российской прокуратуры является прохождение в ней службы всех трех разновидностей: работниками военной прокуратуры - на должностях военной службы; специалистами подразделений правовой статистики, информационных технологий и защиты информации, делопроизводственных и материально-технических подразделений - на должностях государственной гражданской службы; другими работниками органов и организаций прокуратуры, кроме замещающего государственную должность Генерального прокурора, - на должностях государственной службы иного вида, а именно службы в органах и организациях прокуратуры.

В условиях продолжающегося действия большого количества нормативных правовых актов, выделяющих в качестве самостоятельной группы государственных органов правоохранительные органы, нельзя сказать, что с момента принятия федерального закона от 13.07.2015 № 262-Ф3 вся полемика об отнесении того или иного вида государственной службы к правоохранительной службе стала носить исключительно теоретический характер. При этом анализ таких актов по-прежнему не позволяет сделать однозначный вывод об отнесении органов прокуратуры Российской Федерации к числу правоохранительных либо исключении их из данной группы.

Так, устанавливая в ст. 17.12 КоАП РФ ответственность за незаконное ношение форменной одежды со знаками различия, символикой государственных военизированных организаций, правоохранительных или контролирующих органов, в ст. 17.13 КоАП РФ и ст. 320 УК РФ - за разглашение сведений о мерах безопасности, примененных в отношении должностного лица правоохранительного или контролирующего органа, законодатель, безусловно, относит прокуратуру к числу правоохранительных органов, поскольку считать ее военизированной организацией или контролирующим органом (в чистом виде) в силу положений других нормативных правовых актов невозможно.

Аналогичный вывод следует сделать из положений ст. 2 Федерального закона от 20.04.1995 № 45-Ф3 «О государственной защите судей, должностных лиц правоохранительных и контролирующих органов» (в части отнесения прокуроров к числу лиц, подлежащих защите), п. 7 ч. 3 ст. 23 Федерального закона от 27.07.2006 № 152-Ф3 «О персональных данных» (в части наделения уполномоченного органа по защите прав субъектов персональных данных правом направлять материалы о выявленных нарушениях «в органы прокуратуры, другие правоохранительные органы»), ч. 4.1 ст. 17 Федерального закона от 29.12.1994 № 77-Ф3 «Об обязательном экземпляре документов» (в части наделения организаций, централизованно распределяющих обязательный экземпляр, функциями по предоставлению сведений о государственной регистрации документов и копии зарегистрированных документов по запросам «органов государственной власти, судебных и правоохранительных органов»), ч. 5 и 6 ст. 7 Федерального закона от 07.02.2011 № 6-Ф3 «Об общих принципах организации и деятельности контрольно-счетных органов субъектов Российской Федерации и муниципальных образований» и введенной федеральным законом от 27.12.2018 № 559-Ф3 ч. 1.2 ст. 13 Федерального закона от 02.03.2007 № 25Ф3 «О муниципальной службе в Российской Федерации» (в части установления запрета на назначение на отдельные должности в контрольно-счетных органах регионов и муниципальных образований в случае близкого родства или свойства «с руководителями судебных и правоохранительных органов», расположенных на соответствующей территории).

Такой же результат дает анализ норм ч. 3 ст. 80 УИК РФ и абз. 7 п. 2 ч. 2 ст. 33 Федерального закона от 15.07.1995 № 103-Ф3 «О содержании под стражей подозреваемых и 
обвиняемых в совершении преступлений», устанавливающих положения о содержании в отдельных исправительных учреждениях и камерах мест содержания под стражей «бывших работников судов и правоохранительных органов», что в полной мере подтверждается правоприменительной практикой.

Вопреки логике, избранной законодателем в перечисленных выше и ряде других нормативных правовых актов, п. 3 ч. 4 ст. 52 Воздушного кодекса Российской Федерации и п. 9 ч. 4 ст. 11.1 Закона Российской Федерации от 11.03.1992 № 2487-1 «О частной детективной и охранной деятельности в Российской Федерации», устанавливая запрет на прием в службы авиационной безопасности и приобретение правового статуса частного охранника лиц, «досрочно прекративших полномочия по государственной должности или уволенных с государственной службы, в том числе из правоохранительных органов, из органов прокуратуры, судебных органов», по сути, разделили государственную службу в органах прокуратуры и службу в правоохранительных органах.

Подобная непоследовательность законодателя прослеживается и в формулировке нормы п. 11 ч. 1 ст. 2 Федерального закона от 07.02.2011 № 3-Ф3 «О полиции», определяющей одним из направлений деятельности органов полиции государственную защиту «потерпевших, свидетелей и иных участников уголовного судопроизводства, судей, прокуроров, следователей, должностных лиц правоохранительных и контролирующих органов, а также других защищаемых лиц». Таким образом, несмотря на прямую связь данной нормы с вышеприведенными положениями федерального закона «О государственной защите судей, должностных лиц правоохранительных и контролирующих органов» и вопреки концепции последнего, из числа должностных лиц правоохранительных органов, образуя самостоятельные категории, исключаются не только прокуроры, но также и следователи.

Федеральный закон от 07.05.2013 № 78Ф3 «Об уполномоченных по защите прав предпринимателей в Российской Федерации», устанавливая в ч. 3 ст. 5 порядок создания рабочих групп для рассмотрения обращений уполномоченного, и вовсе разделяет на три самостоятельных лагеря органы государственной власти, правоохранительные органы и органы прокуратуры.
Не меньший диссонанс в рассматриваемый вопрос вносят положения п. 6 ч. 13 ст. 62 и п. 1 и 3 ч. 1 ст. 63 Федерального закона от 13.07.2015 № 218-Ф3 «О государственной регистрации недвижимости», которые, определяя перечень субъектов - получателей сведений, содержащихся в ЕГРН, из разряда правоохранительных органов исключают не только органы прокуратуры, но и органы, осуществляющие оперативно-розыскную деятельность, по-видимому относя к правоохранительным исключительно органы, осуществляющие предварительное расследование по уголовным делам.

Выявленная несогласованность нормативно-правовой базы Российской Федерации, по нашему мнению, не позволяет достоверно установить отнесение тех или иных норм к конкретным государственным органам и тем самым выявить общность и особенности административно-правового статуса последних, что в свою очередь препятствует дальнейшему развитию теории административного права в направлении исследования проблем института государственной службы с учетом современных потребностей государственно-правового развития.

Более того, в силу нахождения в поле зрения таких несоответствий норм уголовного законодательства (ст. 320 УК РФ) вполне логично напрашивается вывод об опасности совершенно неприемлемого в уголовном праве расширительного толкования понятия правоохранительного органа на основе усмотрения дознавателя, следователя, прокурора или судейского усмотрения [7, с. 97].

Вместе с тем многообразие правовых актов, по-своему трактующих содержание категории «правоохранительные органы», в настоящее время обусловливает нецелесообразность издания концептуального документа, содержащего единые требования и критерии отнесения государственных органов к числу правоохранительных. Очевидно, что законодатель избрал путь ситуационного определения данной категории - применительно к конкретной сфере правоотношений, регулируемой одним либо группой правовых актов. Руководствуясь данной схемой, в актах, затрагивающих многочисленные сферы общественной жизни (например, КоАП РФ, УК РФ и др.), законодатель использует понятие «правоохранительные органы» в широком смысле, имея в виду все государственные органы, так или ина- 
че задействованные в защите охраняемых нормами таких актов правоотношений. В актах же, регулирующих конкретную сферу либо более узкую группу общественных отношений, законодателем к числу правоохранительных отнесены лишь те органы, которые имеют непосредственное отношение к означенной сфере, в связи с чем в этих нормативных документах категория «правоохранительные органы» используется в усеченном понимании.

Однако даже это не объясняет всю непоследовательность приведенных выше норм отдельных правовых актов, что указывает на необходимость внесения в них корректив.

В сложившейся ситуации, вызванной отсутствием в действующем законодательстве единого понятийного аппарата, законодателем по не совсем понятным причинам выделена такая разновидность службы в государственных органах, как федеральная государственная служба, связанная с правоохранительной деятельностью. Она определена все тем же федеральным законом от 13.07.2015 № 262-Ф3, а также некоторыми другими принятыми в последующем законами и подзаконными актами.

Можно было бы предположить, что целью таких преобразований являлось определение общности различных видов федеральной государственной службы, в том числе системы правовых гарантий их служащих (военнослужащих ряда государственных органов, например ФСБ и Росгвардии, ФСИН России и служащих государственной службы иных видов), учитывая их предназначение в системе государственного управления и во многом схожий характер деятельности. Однако анализ нормативных правовых актов, содержащих указанные положения, свидетельствует, что военная служба к рассматриваемой категории не относится.

Еще большие сомнения в обоснованности предложенных изменений вызывает переход законодателя от раскрытия сущности государственной службы через родовые характеристики госорганов, в которых она осуществляется («правоохранительная служба»), к раскрытию характеристик самого органа через функциональную направленность вида службы («органы, в которых законодательством Российской Федерации предусмотрено прохождение федеральной государственной службы, связанной с правоохранительной деятельностью»). Ситуация усугубляется фактическим отсутстви- ем в законодательстве прямых положений, устанавливающих перечень таких органов. К тому же на сегодняшний день законодатель лишь единожды указывает прямо, кто проходит федеральную государственную службу, связанную с правоохранительной деятельностью, - российское казачество, которое, однако, согласно Федеральному закону от 05.12.2005 № 154-Ф3 «О государственной службе российского казачества», является не государственным органом, а лишь формой самоорганизации граждан казачьим обществом.

В действующем правовом поле единственным нормативным правовым актом, раскрывающим содержание категорий «правоохранительные органы» и «федеральная государственная служба, связанная с правоохранительной деятельностью», является постановление ЦИК России от 25.07.2018 № 170/1398-7, которое, устанавливая, что в утвержденных им методических рекомендациях под сотрудниками правоохранительных органов понимаются граждане, проходящие федеральную государственную службу, связанную с правоохранительной деятельностью, одновременно определяет, что к таким относятся работники органов прокуратуры, сотрудники Следственного комитета, органов внутренних дел, таможенных органов, учреждений и органов уголовно-исполнительной системы и других органов, в полномочия которых входит реализация правоохранительных функций.

В науке административного права можно встретить упоминание и о несколько иных категориях службы, имеющих схожее с рассматриваемой значение.

К примеру, Р. В. Нагорных выделяет государственную службу в правоохранительной сфере, которая определяется им как сложное административно-правовое явление, связанное с профессиональной деятельностью граждан на должностях государственных органов, осуществляющих функции в области защиты прав и интересов граждан от противоправных посягательств, борьбы с преступностью, охраны общественного порядка, обеспечения личной и общественной безопасности, исполнения решений о привлечении к юридической ответственности, а также функции в области ресурсного обеспечения правоохранительных органов, в том числе их кадрового обеспечения [9, с. $10 ; 10 ; 12]$. 
Как видно из наименования обозначенных категорий службы, для определения их содержания первостепенное значение имеет уже не отнесение того или иного государственного органа к разряду правоохранительных, а установление направленности функциональной деятельности конкретного служащего - правоохранительной, контрольно-надзорной и правозащитной.

Несмотря на явную взаимосвязь и взаимное сочетание указанных функций, каждая из них имеет свои особенности и характеризует конкретные виды государственной деятельности, имеющие единую цель - регулирование существующих общественных отношений путем выявления нарушений правовых норм и применения мер воздействия к нарушителям.

В данном аспекте правоохранительная деятельность заключается в применении специально уполномоченными органами мер государственного принуждения в целях охраны прав и свобод, законных интересов общества и государства [7]. Важнейшей составляющей ее содержания является направленность на обеспечение безопасности, законности и правопорядка, борьбу с преступностью, защиту прав и свобод человека и гражданина, противодействие терроризму, организованной преступности [3].

Сущность правозащитной деятельности сводится к отстаиванию в компетентной инстанции с использованием разрешенных законом средств личностных и коллективных интересов, прав и свобод отдельных граждан и общественных объединений [2]. Другими словами, такая деятельность имеет исключительно индивидуальный характер и направлена на восстановление либо только способствование восстановлению уже нарушенного права конкретного гражданина либо группы лиц. Данная деятельность не предполагает наличие у органа, должностного или иного лица, ее осуществляющего, полномочий по применению каких-либо мер воздействия. По большей части она заключается в применении ограниченного арсенала правовых средств.

Контрольно-надзорная деятельность состоит в осуществлении наблюдения за функционированием какого-либо объекта или деятельностью группы лиц (органов государственной власти и местного самоуправления, организаций, физических лиц) с целью устранения отклонений от заданных параметров, выявления и пресечения нарушений законности путем применения мер воздействия (дисциплинарных, административных и др.) [1, с. 286-287; 8, с. 95].

Среди приведенных видов профессиональной деятельности наибольшее сходство имеют правоохранительная и правозащитная, сущность которых, исходя из общности образования данных терминов, сводится к отстаиванию прав, свобод и интересов отдельных лиц и групп людей. Различие же этих видов деятельности обусловлено применяемыми для достижения целей средствами и методами: правоохранительная деятельность предполагает применение принудительно-силовых мер воздействия (включая полномочия в сферах уголовной и административной юрисдикции), правозащитная реализуется исключительно путем обращения в уполномоченные на принятие юридически значимых решений инстанции [18]. Учитывая данные признаки, первый из указанных видов деятельности, очевидно, может осуществляться исключительно государственными органами, второй - как государственными органами и должностными лицами, так и другими лицами, в том числе организациями.

Как видно, каждый из трех указанных видов деятельности в той или иной степени с уверенностью может осуществляться органами прокуратуры (контрольно-надзорные функции - надзор за деятельностью органов публичной власти всех уровней; правозащитные - подача в суд заявления в защиту прав, свобод и законных интересов гражданина, который по состоянию здоровья, возрасту, недееспособности и другим уважительным причинам не может сам обратиться в суд (инвалидов, недееспособных, несовершеннолетних, престарелых), участие прокурора в судопроизводстве по делам, вытекающим из публичных правоотношений [4]; правоохранительные - реализация функций уголовного преследования в суде, функций административного преследования, координация деятельности всей системы правоохранительных органов, принятие комплекса мер прокурорского реагирования в целях устранения фактов нарушения законности, выявленных в ходе осуществления надзорных мероприятий, а также при рассмотрении обращений граждан и организаций).

По-видимому, именно присущие органам прокуратуры признаки, позволяющие отнести их к правозащитным и надзорным 
государственным органам, являются причиной продолжающихся на протяжении длительного периода дискуссий, ставящих под сомнение их признание правоохранительными. Между тем именно это подчеркивает уникальность данных органов, обусловленную осуществлением функций практически во всех сферах общественных отношений, что одновременно требует различных форм такой деятельности и воздействия на нарушителей правопорядка. Органы прокуратуры являются важным гарантом верховенства права в силу принятия на себя важной роли в борьбе с безнаказанностью и обеспечении законности действий всего государства [19, с. $2 ; 21]$.

В данной части следует согласиться с мнением К. И. Амирбекова, полагающего, что прокуратура Российской Федерации осуществляет правоохранительную деятельность, не подменяя при этом иные государственные органы. В данных целях прокуроры наделены законом властно-принудительными полномочиями в сфере как уголовной, так и административной юрисдикции [2, с. 51].

\section{Выводы}

Проведенный анализ позволяет с полной уверенностью отнести службу в органах прокуратуры к категории государственной службы, связанной с правоохранительной деятельностью, которая в свою очередь может быть определена как профессиональная деятельность, осуществляемая от имени государства служащими, занимающими должности в уполномоченных федеральных государственных органах и наделенными в силу закона полномочиями по применению мер государственного принуждения, направленная на охрану законности и правопорядка, защиту прав и свобод человека, общественных и государственных интересов, борьбу с преступлениями и другими правонарушениями либо связанная с выполнением функций внутреннего управления и кадрового обеспечения этих органов. Такая служба реализуется в строгом соответствии с правилами, установленными административно-правовыми нормами, и на основе этических принципов и нравственных начал, формирующих ориентацию служащих на достижение общественно полезных целей и интересов самого государства.

Более детальный анализ рассматриваемого вида службы позволяет также конста- тировать наличие значительного сходства правовой природы статуса федерального государственного служащего органов прокуратуры и организационно-правового регулирования вопросов кадрового обеспечения деятельности органов прокуратуры в целом с аналогичными элементами государственно-служебных отношений в учреждениях и органах уголовно-исполнительной системы [11, с. 17-27], а также иных государственных органов, выполняющих правоохранительные функции по обеспечению безопасности, законности и правопорядка, борьбе с преступностью, защите прав и свобод человека и гражданина.

Наряду с этим административно-правовой статус прокурорского работника содержит целый ряд элементов, свидетельствующих о его исключительности и подтверждающих его особое положение в системе государственной службы, нередко обнаруживающих сходство со статусом лиц, замещающих государственные должности судей.

Такими элементами, отличающими работников прокуратуры, к примеру, от сотрудников уголовно-исполнительной системы, являются особые условия и порядок поступления на службу в органы прокуратуры, ее прохождения, присвоения классных чинов, назначения на должности, прекращения службы, исключительность предоставленных законом полномочий прокурорам, особенности привлечения их к административной и уголовной ответственности.

Вместе с тем следует признать, что на современном этапе наметилось серьезное отставание научной и законодательной деятельности по совершенствованию государственной службы в органах прокуратуры от потребностей государственно-правового развития данной сферы правоотношений, что обусловливает необходимость существенной корректировки и уточнения отдельных элементов административно-правового статуса прокурорского работника.

Субсидиарность положений действующего законодательства в определении статуса прокурорских работников, противоречивость и излишнее дублирование отдельных его норм препятствуют появлению полного и комплексного представления о перечне прав и обязанностей прокурорских работников, системе действующих в отношении их ограничений и запретов, видах их поощрения и ответственности. 
Сложившаяся правотворческая практика урегулирования ключевых элементов правового статуса служащих подзаконными актами, а в ряде случаев и ведомственными ненормативными актами в условиях отсутствия в Законе о прокуратуре соответствующих бланкетных либо отсылочных норм напрямую противоречит основополагающим положениям ст. 10 федерального закона «О системе государственной службы Российской Федерации», а также п. 1 ст. 40 Закона о прокуратуре, в соответствии с которыми правовое положение служащих прокуратуры должно определяться исключительно нормами федерального закона о данном виде государственной службы.

Подобная регламентация фактически подменяет нормы законодательного уровня, что ставит под сомнение возможность принятия установленных такими актами положений в качестве гарантированных государством элементов административноправового статуса служащих органов прокуратуры.

По указанной причине Закон о прокуратуре требует существенной доработки в части дополнения специальной главой, посвященной вопросам прав, обязанностей работников прокуратуры, запретов и ограничений для них.

Сравнительный анализ федеральных законов, регулирующих административно- служебные отношения в государственных органах, осуществляющих правоохранительные функции, в том числе в учреждениях и органах УИС, одновременно приводит к мысли о том, что Закон о прокуратуре подлежит дополнению другими положениями (признаками служащего органов прокуратуры - требованиями, распространяющимися на служащих других государственных органов [21, с. 72-73], элементом денежного содержания - надбавкой за квалификационный уровень (класс), новыми видами мер поощрения и отпусков и др.), что будет способствовать унификации правовых и организационных основ государственной службы в органах, выполняющих правоохранительные функции, соблюдению одного из ключевых принципов построения и функционирования системы государственной службы - единства правовых и организационных основ государственной службы, совершенствованию механизма реализации отдельных элементов административноправового положения работников прокуратуры, обеспечивающего уникальность статуса органов прокуратуры и прокурорских работников в системе института государственной службы в целом. Такие изменения послужат также обеспечению соблюдения высоких нравственных и морально-этических требований, предъявляемых к рассматриваемой категории служащих.

\section{СПИСОК ЛИТЕРАТУРЫ}

1. Административное право : учебник / под редакцией Л. Л. Попова, М. С. Студеникиной. - 2-е изд., перераб. и доп. - Москва : ИНФРА-М, 2019. - 704 с. - ISBN 978-5-16-103786-7.

2. Амирбеков, К. И. Правоохранительная деятельность и правоохранительный орган: понятие и критерии разграничения / К. И. Амирбеков // Российская юстиция. - 2017. - № 4. - С. 48-51.

3. Артемьев, А. М. К вопросу об определении сущности правоохранительной службы и ее структуры / А. М. Артемьев // Российский следователь. - 2008. - № 2. - С. 29-32.

4. Бойченко, С. И. Правозащитная деятельность прокуратуры Российской Федерации: конституционно-правовое исследование : автореферат диссертации на соискание ученой степени кандидата юридических наук / Бойченко Сергей Иванович. - Белгород, 2009. - 46 с.

5. Гришковец, А. А. К вопросу о правоохранительной службе / А. А. Гришковец // Российская юстиция. - 2017. № 7. - С. 59-63.

6. Евстафиади, Я. К. О необходимости законодательного закрепления системы правоохранительных органов России / Я. К. Евстафиади // Административное и муниципальное право. - 2015. - № 6. - С. $603-608$.

7. Козбаненко, В. А. Иные виды государственной службы - правоохранительная служба: закон и доктрина / В. А. Козбаненко // Актуальные проблемы российского права. - 2018. - № 9. - С. 92-101.

8. Масалаб, А. Ф. Проблемы развития государственного контроля и надзора в контексте реформы законодательства / А. Ф. Масалаб // Правоприменение. - 2020. - Том 4, № 4. - C. 94-101. - DOI: 10.24147/2542-1514.2020.4(4).94-101. 9. Нагорных, Р. В. Административно-правовое регулирование государственной службы Российской Федерации в правоохранительной сфере : автореферат диссертации на соискание ученой степени доктора юридических наук / Нагорных Роман Вадимович. - Москва, 2016. - 40 с.

10. Нагорных, Р. В. Ограничения и запреты в системе государственной службы в правоохранительных органах / P. В. Нагорных // Вестник Томского государственного университета. - 2019. - № 447. - C. 241-246. - DOІ 10.17223/15617793/447/29.

11. Нагорных, Р. В. Понятие системы государственной службы в правоохранительной сфере // Всероссийский криминологический журнал. - 2016. - Том 10, № 1. - C. 179-184. - DOI: 10.17150/1996-7756.2016.10(1).179-184.

12. Нагорных, Р. В. Организационно-правовые аспекты кадрового обеспечения деятельности уголовно-исполнительной системы Министерства юстиции Российской Федерации : автореферат диссертации на соискание ученой степени кандидата юридических наук / Нагорных Роман Вадимович. - Москва, 2003. - 32 с. 
13. Назарова, С. П. Институт государственной службы в Российской Федерации: современное состояние и перспективы : автореферат диссертации на соискание ученой степени кандидата юридических наук / Назарова Светлана Петровна. - Ростов-на-Дону, 2011. - 28 с.

14. Погребежский, К. А. Правовое обеспечение государственной правоохранительной службы и пути его совершенствования : автореферат диссертации на соискание ученой степени кандидата юридических наук / Погребежский Константин Александрович - Москва, 2010. - 26 с.

15. Разъяснение Комитета Государственной Думы Федерального Собрания Российской Федерации по федеративному устройству и вопросам местного самоуправления об исключении из системы государственной службы «правоохранительной службы» и включении в нее «государственной службы иных видов» От 06.07.2016. - URL: http://komitet4.km.duma.gov.ru/Voprosy-i-otvety/Razyasneniya-po-otdelnym-voprosam/item/154902 (дата обращения: 01.10.2020).

16. Стелина, Я. Теоретические концепции института государственной службы / Я. Стелина // Правоприменение. 2019. - Том 3, № 2. - C. 21-30. - DOI: 10.24147/2542-1514.2019.3(2).21-30.

17. Тухватуллин, Т. А. Конституционно-правовой механизм назначения прокуроров после внесения поправок в Конституцию Российской Федерации / Т. А.Тухватуллин // Актуальные проблемы российского права. - 2016. - № 12. C. $40-47$.

18. Цымбалюк, Н. И. «Правоохрана» и «правозащита» - идентичность или антиподы в правовом государстве? / Н. И. Цымбалюк // Актуальные вопросы борьбы с преступностью. - 2015. - № 2. - С. 93-98.

19. Dandurand, Y. The role of prosecutors in promoting and strengthening the rule of law / Yvon Dandurand // Crime Law and Social Change. - 2007. - No. 47(4). - Pp. 247-259. - DOI: 10.1007/s10611-007-9070-8. - URL: https://www.researchgate.net/publication/225239037_The_role_of_prosecutors_in_promoting_and_strengthening_the_rule_of_law (accessed 04.01.2021).

20. Nagornykh, R. V. State service in the law enforcement sphere and its major features / R. V. Nagornykh // Penitentiary science. - 2020. - Volume 14, no. 4 (52). - Pp. 576-580. - DOI: 10.46741/ 2686-9764-2020-14-4-576-580.

21. Rosenberg, M. The Attorney General and the Prosecution Function on the Twenty-First Century / Marc Rosenberg // Queen's Law Journal. - 2009. - Volume 43, no. 2. - Pp. 813-862. - URL: https://www.ontariocourts.ca/coa/en/ps/publications/attorney general prosecution function.htm\# ftn3 (accessed 04.01.2021).

22. Shashkova, A. On modifications to the constitution of the Russian Federation in 2020. / A. Shashkova, M. Verlaine, E. Kudryashova // Russian law journal. - 2020. - Volume 8, no. 1. - Pp. 60-83. - DOI: 10.17589/2309-8678-2020-8-160-83.

23. Vedyashkin, S. V. New concept of public service of the Russian Federation in law enforcement: the time has come / S. V. Vedyashkin, R. V. Nagornikh // Вестник Томского государственного университета. Серия : Право. - 2020. № 35. - C. 5-13. - DOI: 10.17223/22253513/35/1.

\section{REFERENCES}

1. Popov L.L., Studenikina M.S. Administrativnoe pravo: uchebnik [Administrative law. Textbook]. 2nd edition, revised and supplemented. Moscow: INFRA-M, 2019. $704 \mathrm{p}$

2. Amirbeko K.I. Law enforcement activity and law enforcement agency: the concept and criteria of differentiation. Rossiiskaya yustitsiya=Russian Justice, 2017, no. 4, pp. 48-51. (In Russ.).

3. Artem'ev A.M. On the question of determining the essence of law enforcement service and its structure. Rossiiskii sledovatel'=Russian Investigator, 2008, no. 2, pp. 29-32. (In Russ.).

4. Boichenko S. I. Pravozashchitnaya deyatel'nost' prokuratury Rossiiskoi Federatsii: konstitutsionno-pravovoe issledovanie: avtoreferat dissertatsii na soiskanie uchenoi stepeni kandidata yuridicheskikh nauk [Law protecting activity of the prosecutor's office of the Russian Federation: constitutional and legal research: Candidate of Sciences (Law) dissertation abstract]. Belgorod, 2009. 46 p.

5. Grishkovets A.A. On the question of law enforcement service. Rossiiskaya yustitsiya=Russian Justice, 2017, no. 7, pp. 59-63. (In Russ.).

6. Evstafiadi Ya.K. About the need for legislative consolidation of the law enforcement system in Russia. Administrativnoe $i$ munitsipal'noe pravo=Administrative and Municipal Law, 2015, no. 6, pp. 603-608. (In Russ.).

7. Kozbanenko V.A. Other types of state service - law enforcement service: law and doctrine. Aktual'nye problemy rossiiskogo prava=Topical Issues of Russian Law, 2018, no. 9, pp. 92-101. (In Russ.).

8. Masalab A.F. Problems of development of state control and supervision in the context of legislative reform. Pravoprimenenie=Law Enforcement Review, 2020, vol. 4, no. 4, pp. 94-101. DOI: 10.24147/2542-1514.2020.4(4).94-101. (In Russ.).

9. Nagornykh R.V. Administrativno-pravovoe regulirovanie gosudarstvennoi sluzhby Rossiiskoi Federatsii $v$ pravookhranitel'noi sfere: avtoreferat dissertatsii na soiskanie uchenoi stepeni doktora yuridicheskikh nauk [Administrative and legal regulation of state service of the Russian Federation in the law enforcement sphere: Doctor of Sciences (Law) dissertation abstract]. Moscow, 2016. 40 p.

10. Nagornykh R.V. Restrictions and prohibitions in the system of state service in law enforcement agencies. Vestnik Tomskogo gosudarstvennogo universiteta=Tomsk State University Journal, 2019, no. 447, pp. 241-246. DOI: 10.17223/15617793/447/29. (In Russ.).

11. Nagornykh R.V. The concept of the system of state service in the law enforcement sphere. Vserossiiskii kriminologicheskii zhurnal=All-Russian Criminological Journal, 2016, vol. 10, no. 1, pp. 179-184. DOI: 10.17150/1996-7756.2016.10(1).179184. (In Russ.).

12. Nagornykh R.V. Organizatsionno-pravovye aspekty kadrovogo obespecheniya deyatel'nosti ugolovno-ispolnitel'noi sistemy Ministerstva yustitsii Rossiiskoi Federatsii: avtoreferat dissertatsii na soiskanie uchenoi stepeni kandidata yuridicheskikh nauk [Organizational and legal aspects of staffing for the activities of the penal system of the Ministry of Justice of the Russian Federation: Candidate of Sciences (Law) dissertation abstract]. Moscow, 2003. $32 \mathrm{p}$.

13. Nazarova S.P. Institut gosudarstvennoi sluzhby v Rossiiskoi Federatsii: sovremennoe sostoyanie i perspektivy: avtoreferat dissertatsii na soiskanie uchenoi stepeni kandidata yuridicheskikh nauk [The institution of state service in the Russian Federation: current state and prospects: Candidate of Sciences (Law) dissertation abstract]. Rostov-on-Don, 2011. 28 p. 
14. Pogrebezhskii K.A. Pravovoe obespechenie gosudarstvennoi pravookhranitel'noi sluzhbyiputiego sovershenstvovaniya: avtoreferat dissertatsii na soiskanie uchenoi stepeni kandidata yuridicheskikh nauk [Legal support of the state law enforcement service and ways of its improvement: Candidate of Sciences (Law) dissertation abstract]. Moscow, 2010. 26 p. 15. Raz"yasnenie Komiteta Gosudarstvennoi Dumy Federal'nogo Sobraniya Rossiiskoi Federatsii po federativnomu ustroistvu i voprosam mestnogo samoupravleniya ob isklyuchenii iz sistemy gosudarstvennoi sluzhby "pravookhranitel'noi sluzhby" i vklyuchenii v nee "gosudarstvennoi sluzhby inykh vidov" ot 06.07.2016 [Explanation of the Committee of State Duma of the Federal Assembly of the Russian Federation on the federal structure and questions of local government on the exclusion of "law enforcement service" from state service and inclusion of "state service of other types" in state service dated July 6, 2016]. Available at: http://komitet4.km.duma.gov.ru/Voprosy-i-otvety/Razyasneniya-po-otdelnymvoprosam/item/154902 (accessed October 1, 2020). (In Russ.).

16. Stelina Ya. Theoretical concepts of the law of civil servants. Pravoprimenenie=Law Enforcement Review, 2019, vol. 3, no. 2, pp. 21-30. DOI: 10.24147/2542-1514.2019.3(2).21-30. (In Russ.).

17. Tukhvatullin T.A. Constitutional and legal mechanism for the appointment of prosecutors after the amendment of the Constitution of the Russian Federation. Aktual'nye problemy rossiiskogo prava=Topical Issues of Russian Law, 2016, no. 12, pp. 40-47. (In Russ.).

18. Tsymbalyuk N. I. "Pravookhrana" and "pravozashchita" - similarity or antipodes in a legal state? Aktual'nye voprosy bor'by s prestupnost'yu=Topical Issues of Combating Crime, 2015, no. 2, pp. 93-98. (In Russ.).

19. Dandurand Y. The role of prosecutors in promoting and strengthening the rule of law. Crime Law and Social Change, 2007, no. 47 (4), pp. 247-259. DOI: 10.1007/s10611-007-9070-8. Available at: https://www.researchgate.net/ publication/225239037_The_role_of_prosecutors_in_promoting_and_strengthening_the_rule_of_law (accessed January 4, 2021).

20. Nagornykh R. V. State service in the law enforcement sphere and its major features. Penitentiary Science, 2020, vol. 14, no. 4 (52), pp. 576-580. DOI: 10.46741/ 2686-9764-2020-14-4-576-580. (In Russ.).

21. Rosenberg M. The attorney general and the prosecution function in the twenty-first century. Queen's Law Journal, 2009, vol. 43, no. 2, pp. 813-862. Available at: https://www.ontariocourts.ca/coa/en/ps/publications/attorney_general_ prosecution_function.htm\#_ftn3 (accessed January 4, 2021).

22. Shashkova A., Verlaine M., Kudryashova E. On modifications to the constitution of the Russian Federation in 2020. Russian Law Journal, 2020, vol. 8, no. 1, pp. 60-83. DOI: 10.17589/2309-8678-2020-8-1-60-83.

23. Vedyashkin S.V., Nagornikh R.V. New concept of public service of the Russian Federation in law enforcement: the time has come. Vestnik Tomskogo gosudarstvennogo universiteta. Pravo=Tomsk State University Journal of Law, 2020, no. 35, pp. 5-13. DOI: 10.17223/22253513/35/1. (In Russ.).

\section{ИНФОРМАЦИЯ ОБ АВТОРЕ / INFORMАTION AВOUT THE AUTHOR}

АНДРЕЙ ВАСИЛЬЕВИЧ СМИРНОВ - СТарШИЙ СОВеТник юстиции, старший помощник прокурора Вологодской области по взаимодействию с законодательными (представительными) и исполнительными органами области, органами местного самоуправления, правовому обеспечению, г. Вологда, Российская Федерация. ORCID: https://orcid.org/0000-0003-0560-0841, e-mail: smirnov5146@yandex.ru
ANDREI V. SMIRNOV - Senior Councilor of Justice, senior assistant prosecutor of the Vologda Oblast for interaction with legislative (representative) and executive authorities of the oblast, local governments, and legal support, Vologda, Russian Federation. ORCID: https://orcid.org/0000-00030560-0841, e-mail: smirnov5146@yandex.ru 